\title{
Bernard Shaw's Admirable Bashville: Playwright and Prizefighter
}
Authors' contribution:
A) conception and design of the study
B) acquisition of data
C) analysis and interpretation of data
D) manuscript preparation
E) obtaining funding

\author{
Jorge Knijnik $^{1 \text { A-E }}$, Bob Petersen ${ }^{2}$ A-E \\ ${ }^{I}$ University of Western Sydney, School of Education (NSW, Australia) \\ ${ }^{2}$ Independent scholar (NSW, Australia)
}

ABSTRACT

Bernard Shaw's little blank-verse play, The Admirable Bashville, or, Constancy
Unrewarded is a play where two types of performance, sport and drama, interact on
the stage. It was written in 1901 and it was performed three times in London under
Shaw's auspices in 1901, in 1904, and in January-February 1909. Its next
performance was in Vienna in 1924; then it was performed in Sydney in 1927. Shaw
was an enthusiastic admirer of the bare - knuckled art of fighting, though he has
written Bashville as a portrait of a period when this art was disapearing to be
replaced by the noble art of boxing, under the new Queenberry's rulling. This essay
examines both the play itself, throwing new lights over obscur characters of the play,
such as Cetewayo the Black African king, and even over Bashville, the prize-fighter.
As copyrights laws of that period did not guarantee Shaw's rights over his works,
the paper shows Shaw's attempts to keep the copyrights over his work, by
performing the play as many times and under any conditions. Under copyright laws
he could lose all his rights if the play were performed by other producers
beforehand. The Admirable Bashville is a minor play by a major playwright, and
Shaw never pretended it was anything more.
Bernard Shaw, Admirable Bashville, prizefighting KEYWORDS

"Voulez-vous jouer avec moâ?" When Marcel Achard wrote his first play in 1922 he was playing with words; on the stage, he was also playing with the public, inviting the ones who were supposed to be passive spectators, to come up and play with the actors in clown costume. It is not certain how many accepted the invitation. Would you like to play with me? carries also more ambiguity, as jouer, or play, can be understood as a child's game, but also what actors do, or the actions of a sport player. Achard built plenty of action, some of it athletic, into the play.

The combination between these two different sorts of performance (sport and theatre) has been explored since then in different ways. One of the most contemporary is the so-called "Ligue Nationale d'Improvisation" which started in 1977 in Quebec, with an adaptation of the game of hockey to the theatre, a sort of improvisation which, since those days, remains a very popular event in Canada, as a way, its promoters say, to "break down the high art/low art divide (...) a potent way to break down the theatre's fourth wall, the distance between actor and spectator" (Arroyos, 2010, p. 13).

Performance can have different meanings. While writing the possible various meanings of performance, Benston states that this term has a high prestige in "contemporary culture [as it] can be traced 
to modernity's recession from the Real" (Benstson, 1992, p. 436) Most recently, Crane assumes that "modernity has put a binary distinction between the performed and the real in which what is performed in 'only' or 'just an inferior representation of a prior reality'”' (Crane, 2002, p. 169).

What does happen when the sport activity, just a performance by itself, meets another way to perform? Is it not our aim in this paper to go deeper in this point; however, it is interesting to recall that the $19^{\text {th }}$ Century theater often dealt with sport (horse-racing for example) using ingenious scenic devices. And in the many performances of As You Like It there was always a strong man (often a boxer) to play Charles the Wrestler. We will discuss a play which puts on the stage one sort of sportive performance: prize fighting in England, America, and Australia as well as other European countries and even South Africa. The play we discuss was written by Bernard Shaw in 1901: The Admirable Bashville, or, Constancy Unrewarded. It was one of the first plays about prizefighting to rise above the "Corinthian Tom and Jerry" dramas. In his sophisticated study of The Art and Aesthetics of Boxing, Scott (2008) characterised boxing as theatrical in its ring setting, and spectacular; but did not discuss theatrical presentations of boxing spectacle like The Admirable Bashville.

Cashel Byron is the Australian heavyweight champion, who still fights with bare knuckles, no gloves, a thing that was forbidden by the new Queensberry Rules - the 'civilized boxing' with gloves. He encounters Lydia, a lady who falls in love with him, we gather because he is handsome and brawny.

"Lives in this castle! Owns this park! A lady

Marry a prizefighter! Impossible. And yet the prizefighter must marry her".

And he does, but only after his gentlemanly qualifications are revealed (Holroyd, 1998, p. 63).

The most peculiar thing about The Admirable Bashville is that the dialogue is in blank verse. At the preface of the play, Shaw explains why he wrote this play in iambic pentameters.

"My answer is that I had but a week to write it in. Blank verse is so childishly easy and expeditious (...) that by adopting it I was enabled to do within the week what would have cost me a month in prose" (Shaw, 1927, p. 287).

Between April 1882 and February 1883 Shaw had written Cashel Byron's Profession, a novel about a bare-knuckle prizefighter. It was rejected by half a dozen publishers until To-Day: the monthly magazine of scientific socialism issued it in parts between April 1885 and March 1886, whereupon it was printed as a book in 2500 copies by the Modern Press, with pale green paper at one shilling. In effect it was still-born: in 1887 it was on sale in only one London shop, Simpkin Marshall's in Paternoster Row. "Our London Correspondent", whose columns were syndicated across the British Empire, reported: "I had a tremendous hunt for it" ". Shaw himself said of it, in a notice of his own fiction for the Novel Review in February 1892, that the novel was still extant, retailed at ninepence by London discount bookseller, and that:

"the late James Runciman, himself, I understand, an amateur boxer of some distinction, wanted to dramatise Cashel Byron's Profession, an enterprise from which I strongly dissuaded him on the ground that the means which I had individualised the characters in the novel would prove quite ineffectual on the stage; so that all that could be done was, not to dramatise the novel, but to take the persons out of it, and use them over again on the stage in an otherwise original play lest there should be any heir to Runciman's design" (Tyson, 1996, p. 97).

Runciman (1851-1892) was an essayist and writer of proletarian fiction. The novel was obscure. Shaw told an American correspondent in 1899 that his wife (whom he met in 1896) had never even heard of Cashel Byron's Profession.

Shaw did not change his mind. Forty years later in a letter of 1930 to his friend the ex-champion heavyweight boxer Gene Tunney, Shaw said of his novel that "there is not a single reality likeable character in it":

"Cashel, though honest and super competent professionally, is selfish and limited; the lady is a

\footnotetext{
${ }^{1}$ South Australian Advertiser, 2/28/1887.
} 
prig and a bluestocking; his relations with his egotistical actress-mother are odious; the other girl is humiliated by her poverty and has to marry a man she doesn't respect; and the only real hero in the plot is the footman Bashville: in fact I made him the titular hero when I had to dramatise the novel in a burlesque to keep Corbett's travesty out of London" (Holroyd, 1991, pp. 210-211).

We will return to Corbett shortly.

In 1887 a New York edition of Cashel Byron's Profession appeared in the Harper and Brothers "Handy" Series and fell stone dead. Twelve years later the book was published by Walter Scott in London, in their "Novocastrian Series". Then two editions appeared in New York, one by Brentano's in 1899. These editions sold well enough and brought Shaw's boxing book to the attention of many Americans. One of them, the actor Harrison Wolfe, set out to turn it into a play that would be a vehicle for himself. He opened in New York in the last days of December, 1900. The run at the Herald Square theatre was short. It was severely panned by the papers, the New York Times criticizing Wolfe's play itself as incompetent, tedious and humourless. As to the performances:

"Mr. Harrison Wolfe, who made this play, and posed and spouted as the hero, is a fairly good-

looking young man who should learn to stand to walk and to use his voice if he intends to stay

on the stage. He is a dreadfully bad actor, and most of his associates are actors of the same sort $^{\prime 2}$.

The sting secreted in this criticism was that Wolfe was 42 years old. In January 1906 Corbett denied to the Evening World that he had played Cashel Byron some years before. "'That was Harrison Wolfe', he said. 'I saw the performance. It was Wolfe's version"'. It is unlikely that Wolfe intended to take his play to England, and he carried it only to whistle-stops in the mid-west.

In those years the United States had not signed and endorsed the Berne Convention on copyright, and in America anybody could freely republish things that had been published in Britain or elsewhere. Shaw had given away any hope of dollars for his works when they were pirated, but he resented people adapting his plays and bowdlerizing them, and reworking his novels into plays. But this is what Harrison Wolfe did in 1900. Then Shaw discovered that anyone in Britain itself could take one of his novels and turn it into a play which, if acted once, became their property and not his. In his preface, Shaw wrote that after the republishing of the novel in New York:

"rumours soon reached me of several American stage versions; and one of these has actually

been played in New York, with the boxing scenes under the management (so it is stated) of the eminent pugilist Mr. James Corbett" (Shaw, 1927, preface pp. 03).

There was a hint that the production itself was to follow. To circumvent this eventuality he turned Cashel Byron's Profession into a play, calling it The Admirable Bashville. As Shaw writes in the first statement of the preface: "The Admirable Bashville is a product of the British law of copyright".

He sat down in January 1901 and wrote the play in a week, finishing it on February 2 of the same year. But as he had adumbrated in 1896, he did not transpose the novel into stage terms. He then had a token cast give one token performance in a London theatre, the statutory once, to give him copyright and prevent interlopers American or other. The text of The Admirable Bashville was published by Grant Richards in October 1901 bound in with a new edition of Cashel Byron's Profession and accompanied by the 'Essay on Modern Prizefighting'. An amateur production followed in December 1902. The first public performances of The Admirable Bashville came two years after that legitimating performance, by the Stage Society at the Imperial Theater on June 7 and 8, 1903 with Ben Webster as Cashel and Henrietta Watson as Lydia. Cetawayo was played by the Shakespearean actor James Hearn in blackface (Holroyd, 1989, p. 64).

James Huneker, who was writing for the New York Sun at the time, on May 17, 1903 reported of Cashel Byron's Profession that "it was even dramatized in this country", and then on August 2, 1903, in an

\footnotetext{
${ }^{2}$ New York Times, December 28, 1900.
} 
article headed "London Plays and Music", he said that "as there had been a dramatization made unauthorized - for a well-known American pugilist-actor, Mr. Shaw thought that he had better protect his English interests. Hence the parody for copyright purposes". Harrison Wolfe was hardly well known as an actor-pugilist, so it may be that Corbett, if he did not choreograph the boxing scenes, had manifested a fleeting interest at the time. In 1930 Shaw fingered Corbett as the provocation for The Admirable Bashville and Huneker implied Corbett in 1903, but according to Armond Fields in his study of Corbett as entertainer, it was not until 1905 that "Gentleman Jim", looking around for another stage vehicle for his acting talents, had Stanislas Strange turn Cashel Byron's Profession into a play (Fields, 2001). Strange did this regularly: he turned Shaw's Arms and the Man into The Chocolate Soldier in 1909. Maybe Corbett had choreographed the boxing in the 1900 play, and then distanced himself from his work. So in January 1906 a play called Cashel Byron's Profession was put on in New York, this one starring Corbett, with Margaret Wycheley as Lydia. It lasted two weeks at Daley's Theater then moved to the Majestic, and then to Proctor's $125^{\text {th }}$ Street Theater in mid-February. We do not hear of any more plays concocted from the novel.

The Admirable Bashville itself has not had many performances over the century, at least not by professional actors. In 1903 Shaw declined to have it performed before German audiences, because "the hero is a prizefighter and Germans know nothing about English Prizefighting, and would not enjoy a burlesque of it" (Weiss, 1986, p. 247); but in 1924, when Max Schmeling had already turned professional, it was translated as Der Boxkampf and, starring Jakob Feldhammer as Cashel, had a short run in Vienna (Weiss, 1986). It can be noted that Duncan Macdougall read it in Sydney, Australia, in $1927^{3}$, and that in 1929 it was performed at the Malvern Festival, with Shaw in attendance. The most prestigious cast performed it at Lilian Baylis' Old Vic in 1933. Several actors in it went on to fame in the movies in later decades: Roger Livesey, Anthony Quayle and Marius Goring; along with the Lydia (Valerie Tudor) who only made a couple of films in 1939. Alastair Sim played Cetewayo. It was performed, having "never before been presented in New York", at the Cherry Lane Theater in Greenwich Village in 1956, and won for its star, Frances Sternhagen, the Distinguished Performance (actress) prize among the first OBIE awards, as well as the Clarence Derwent Awardi. In July 1984 it was performed in London, by the Regents Park Open Air Theatre company. On May 21, 2007 it was performed by the Gingold Theatrical Group in New York as part of their cyclical reading through all Shaw's plays over four years, Marc Kudisch playing Cashel and Lacey Kohl playing Lydia, with as Cetewayo perhaps the first Black to play the part, Kevin Joseph Rennard. It recurred in the cycle in April, 2013 with Jeremy Bobb as Cashel, Heidi Armbruster as Lydia, and Rennard reprising the part of Cetewayo. Apart from these occasions, because it is short it seems to have been most often performed by amateur groups like Brown University's "Sock and Buskin" dramatic society in 1936. As an aside, it was twice given a musical setting: as Bashville by Dennis King and Benny Green (1983) and as Bashville in Love (1998) by Michael Valenti and Charles Marowitz.

\section{Boxing- and masculinities - on the stage}

Over Bashville the footman I howled with derision and delight. I dote on Bashville: I could read of him for ever: de Bashville je suis le fervent: there is only one Bashville; and I am his devoted slave: Bashville est magnifique; mais il n'est guère possible. Robert Louis Stevenson (In Shaw, 1927, p. 3 ) $^{4}$.

This was bold, to put a boxing match on the stage before mixed audiences - both in 1900 and 1906 and in The Admirable Bashville. Boxing, or at least prize fighting, was banned in most parts of the United States, and it was not considered at all a suitable spectacle for ladies. The Uncle Tom's Cabin touring company of 1893-94, headlined by the boxer Peter Jackson, had featured three rounds of sparring at the end

\footnotetext{
${ }^{3}$ Sydney Morning Herald, 3/5/1927.

${ }^{4}$ Stevenson (1850-1894) author of The Strange Case of Dr. Jekyll and Mr. Hyde, among others.
} 
of Act I, but they were not part of the performance and ladies could withdraw - though it seems they did not (Petersen, 2011). The early boxing movies described by Streible in his Fight Films were said to be welcomed by ladies because they included no thuds from punching and of course no red blood.

The lady in this play, Lydia, is forbidden to talk to this sort of sportsman, like the prizefighting men who suddenly arrived in her property. Cashel does not know who she is, and after she asked where he is coming from and who he actually is, he takes her in his arms and put her seated on her feet. Lydia, panting, says:

"You take away my breath! You're strong

You take away my breath! You are strong. Your hands off, please. Thank you. Farewell” (Shaw, 1927, p. 8).

Cashel still does not know who she is. He took Lydia to be "the daughter of some farmer". Suddenly, she reveals that she is the lady of the castle. He is ashamed, and tries to hide his real identity; he cannot tell her he is a prizefighter. Mellish, his trainer, approaches. "Coo-ee!" Mellish yells, revealing his Australian background. He saw Cashel talking to Lydia, and what follows is a speech fully of instructions of a construction of a real prizefighter, or a real man. What we can see at this moment of the play is Shaw revealing the masculinity of the fighter. Mellish call himself of 'Trainer of heroes, builder-up of brawn'. He cannot admit a fighter with 'flaccid muscles and with failing breath'. He challenges Cashel to leave the woman, as he thinks Cashel has a duty to be done, a fight to be fight, and he needs to prepare himself for it and women are a distraction of his duty. At the end of the first act, Mellish express all his ideology of the masculine character of the player: "What makes a man but duty?" After some rough dialogues between Mellish and Cashel about what the real duty is, the latter punches the first, who falls down unconscious. Cashel has demonstrated his "colossal force", the force of a prizefighter, an example of a man.

Here, the embodiment of the hero, the hegemonic male, is clearly demonstrated - firstly, Lydia acclaims his force, and now Cashel, despite his duty, shows again his dominant position by using his powerful male body. In the middle of many potential social order destabilisers, the display of the strong and violent male body serves as a symbolic act to "stabilize a structure of domination (...) in the gender order" (Messner, 1990, p. 215). As suggested by the author, combat sports are one of the most important arenas where gender differences and inequalities can be constructed and "naturalized".

In the second act young Bashville, a humble servant in Lydia's household, makes his appearance on the stage. He is desperately in love with Lydia -desperately, because his dream is impossible. Lydia finds out who Cashel is - and his profession. She does not seem too worried about it, as she argues with her cousin Lucian that Cashel is literate and can quote Shakespeare unconsciously. She even cheers while Bashville reads the newspaper with the details of Cashel's latest fights. Cashel arrives, and all the discussions and dialogues are again about the honour of a men, the courage of a prizefighter: Cashel's extraordinary strength that allows his masculinity to shine and dominate over other "weak" masculinities. However, Cashel argues that he is a professional so he would only fight professional prizefighters: to preserve his prestige and honour he refuses to fight 'an amateur'. Also, even if Cashel's masculinity is sustained at the top of the gender order by his strength, Shaw makes clear that there is a flux of masculinities, therefore power, along the play. Nothing will remain the same forever - even the gender order (Coles 2009).

Lydia and Cashel are in love. She insists that he abandon his profession to become a "gentleman"

"To be a prizefighter, and maul poor mariners

With naked knuckles, is no work for you"(Shaw, 1927, p. 18).

Cashel is reluctant. He does not want to abandon his "lightning hand", his "springing muscle". Lydia is insisting, and Cashel argues how valuable is his profession, his sport: "Hath slain no sentient creature for my sport (...) It is a lonely thing to be a champion". While they are arguing, Bashville enters on the stage advising Lydia that her carriage is now ready. Cashel suddenly becomes worried, as he has to meet 'a monarch, a king'. Cashel starts a discussion with Bashville, who gets angry, and hits Cashel on the nose. Cashel bleeds, but is happy, as he sees the qualities of a real fighter in Bashville: "Too quick for me! There's 
money in this youth".

The next scene is a boxing match between Cashel and William Paradise in the Agricultural Hall in Islington, a huge venue. Shaw features a black king, Cetewayo, the king Cashel mentioned early in this act. The play will concentrate many actions around this character. Before trying to expand on Cetewayo, while not performing an exegesis on Cashel Byron's Profession, it is useful to understand that in the 1885 novel the African king is not named, nor does he speak more than a few words of broken English and needs interpreters. In fact he is almost a non-person at the boxing match, though he does offer the victorious Cashel three wives. Whereas here in 1901 he is named and speaks most eloquently. Cetewayo, the usual English name of the Zulu king Cetshwayo kaMpanda, was politely under arrest in London at the time Shaw was writing Cashel Byron's Profession, and is said by Stanley Weintraub to have been Shaw's first hero (Weinstraub 1999). The Admirable Bashville takes place, in effect, in July 1882. Shaw almost certainly knew Lady Florence Dixie's books on Cetewayo (1882); and that she was the sister of Sholto Douglas the Marquess of Queensberry. Moreover, the London venue of the Queensberry cups contest, Lillie-bridge Park, which Shaw frequented, featured a hot-air balloon with on it in large letters: CETEWAYO. Cetewayo spent the month of July 1882 in London, paying his respects to Queen Victoria, being dined by the Merchants of London, visiting the Zoo, attending a performance at the Gaiety, having his portrait taken by Alexander Bassano the society photographer, and taking a boxing lesson from an Englishman referred to jokingly as "India-rubber Bill". This was almost certainly the ponderous Bill Richardson and the venue his Blue Anchor boxing hall in Shoreditch, which Shaw used to attend and which is referred to by name in the play. Cetewayo was reported by the Penny Illustrated Paper on August 12 (p. 7) as saying that

"I did box in a sporting crib-surrounded wid all de 'patricians' in London - pale-faced little men in black clothes, wid tiny dogs under dare arms. Uncommonly thirsty were dose same patricians".

But he was nevertheless a political prisoner, being punished for the disastrous English defeat at Isandlwana and the massacre at Rorke's Drift. He was released back to Zululand in 1883 but died soon after that.

Shaw uses Cetewayo to question British imperialism and its essence: the conquest of non-European people.

Cetewayo remarks, on entering the Agricultural Hall: "Are these anaemic dogs the English people?", whereupon he is told that he is a savage, reasoning like a child, because the English have technological mastery, being able to build steam engines and lay undersea cables. Cetewayo retorts that "men become civilized through twin diseases, terror and greed", which are the "grisly parents of invention". He says that death and dread over-run the earth, and their white-livered slaves through chattering teeth stammer the words "Survival of the Fittest" as they steal unearned gold. He calls the boxers "two white-faced ones who dare fight without guns, and spearless", according to rules that ensure they will not get killed; and he offers the winner six wives if he kills the other. Cetewayo calls this boxing "personified pusillamity", and is told again that he is a rude untutored savage who cannot understand that "English" and "brave" are synonymous. In effect his speeches constitute a diatribe against English imperialism.

At the end of the scene, Cetewayo and his attendants start a riot, yelling out "Isandlwana and Victory!", "Victory and Isandlwana!". Cashel knocks them down because they are effectively trampling on the English flag, and the Africans on their knees surrender. Cetewayo asks, "Have I been struck by lightning?" and he is told, "Sir, your conduct can only be described as most ungentlemanly". So the English ideas of empire and manliness coalesce.

Shaw was thereby, through his black hero, voicing his criticism of the British Empire. But there may have been another reason why Cetewayo was placed prominently in The Admirable Bashville. In the United States conventionally, if not as a rule, Blacks did not appear on the stage with Whites. Certainly when Corbett was creating his Cashel Byron's Profession play in 1905, Fields tells us that the Africans of the novel were written out and "Indians" substituted, creating a confusion that had to be eliminated (Fields, 2001, 
p. 150). In the cast of the 1906 performance no notably Native American names show up. Certainly Cetewayo could have been played by a White in blackface, his attendants too - but how many White actors would have been willing to deliver Shaw's lines? By writing so large a part for a Black, and making him scorn White bodies, Shaw may have been ensuring The Admirable Bashville was unplayable in the United States, and indeed a professional performance there had to wait until 1956, and an African-American Cetewayo until 2007.

It is worthwhile to explain that in Act III Cashel gives up of being a prizefighter and is recognized as "the son and heir of Bingey Bumpkin FitzAlgernon de Courcy Cashel Byron, Sieur of Park lane and Overlord of Dorset"; which is to say, any association of boxing with lower-class men is erased. He marries Lydia, we assume, though continuing his involvement with sports, with prizefighting, now promoting the young Bashville as a promising fighter. As Bashville reluctantly agrees to become a boxer, all cheer him "Hail, Byron's novice, champion that shall be!".

Bernard Shaw loved boxing and fights. As stated above, Shaw wrote an essay on modern prizefighting at the end of the revised edition of Cashel Byron's Profession and this essay was published at the end of The Admirable Bashville as well. In his essay, Shaw demonstrates how he rather prefers the bare knuckles and the prizefighting that it generates, to boxing with gloves. He argues that bare knuckles are not so dangerous as fights with gloves, and he complains about the agony of the first. In this essay, Shaw shows himself to be a great connoisseur of the sports world, and also complains of the gambling around boxing (gambling is "the main pillar of the sporting world", he states). However, Shaw realized that the public opinion desired a law to protect themselves from the violence of a prizefighter, then fighting with no gloves was forbidden, and what happened was the "legalization of prizefighting under cover of the boxing glove". Then Shaw continued to appreciate fights, even if his favourite fight, with two men fighting with naked knuckles, was disappearing. This appreciation changed his life in a way one can never imagine.

Shaw had few close friends but, curiously, among them was an undefeated world champion boxer, Gene Tunney. Tunney's son wrote a book about Shaw and Tunney's friendship, trying to find out what was the reason for such strong relationship between two men who were so different.

“Bernard Shaw shared Gene Tunney's love for boxing, and Tunney shared Shaw's passion for books and ideas. It was the key to their relationship - it allowed each of them to validate the other by being keenly interested in each other's fields of activity and supreme accomplishments" (Tunney, 2003, p.150).

This friendship grew quite intense, their two families going on vacation together. The former boxer called himself a pupil and Shaw his master, a master who loved boxing. Before they met, Hollywood had made offers to both to adapt Cashel Byron's Profession for the screen, with Tunney playing the central role. Both men refused, for different reasons, but also for their dislike of Hollywood's productions. At that time, Cashel Byron was already adapted to theatre, and even The Admirable Bashville being a "fast" adaptation of the novel, it might have been worthwhile to see how the theatre performance would translate to the screen. Cashel Byron as well as The Admirable Bashville takes account of this passion, and connects playwright to the prizefighter by literature. But a movie of Cashel Byron's Profession was never made in Hollywood -only in Czechoslovakia where it was filmed in 1921 as Román Boxera, with Frank Rose-Ruzicka as the Cashel (Holroyd, 1991, p. 374).

To conclude: The Admirable Bashville is a minor play by a major playwright, and Shaw never pretended it was anything more. Even Benny Green in his Shaw's Champions does not give it a chapter, only some scattered paragraphs, yet this was the man who five years later turned it into a musical. In his Noble Art, Sawyer deals with Cashel Byron's Profession though not with The Admirable Bashville; but it does get a mention in Boddy's amazing history of the ring (Sawyer, 1989; Boddy, 2008). It is historically interesting, however, because it is almost the only play of that period still in the repertoire where a pugilist is the hero and at the heart of the action is what James Huneker in 1903 called "the noble art of sluggerei" a boxing match. 


\section{REFERENCES}

Achard, M. (1924). Voulez-Vouz Jouer Avec Moa?:Trois Actes. Paris: BOG.

Arroyos, F. (2010). La Ligue Nationale D'improvisation: Hockey's Contribution to Theatresports. CTR - Canadian Theatre Review, 143, 11-16.

Benston, K.W. (1992). Being There: Performance as Mise-En-Scene, Abscene, Obscene, and Other Scene. PMLA, 107, 3, 434-49.

Boddy, K. (2008). Boxing: A Cultural History. London: Reaktion Books.

Coles, T. (2009). Negotiating the Field of Masculinity The Production and Reproduction of Multiple Dominant Masculinities. Men and Masculinities, 12(1), 30-44.

Crane, M.T. (2002). What Was Performance? Criticism, 43, 2, 169-87.

Fields, A. (2001). James J. Corbett: A Biography of the Heavyweight Boxing Champion and Popular Theater Headliner. Jefferson (NC): McFarland.

Green, B. (1978). Shaw's Champions: G.B.S. and prizefighting from Cashel Byron to Gene Tunney. London, Elm Tree Books.

Holroyd, M.(1998). Bernard Shaw, I: 1856-1898, the search for love. London: Chatto \& Windus,

Holroyd, M. (1989). Bernard Shaw, II: 1898-1918, the pursuit of power. London: Chatto \& Windus.

Holroyd, M. (1991). Bernard Shaw, III: 1898-1950, the lure of fantasy. London: Chatto \& Windus.

Messner, M. (1990). When bodies are weapons: Masculinity and violence in sport. International Review for the Sociology of Sport, 25(3), 203-20.

Petersen, B. (2011). Peter Jackson the Boxer. Jefferson: McFarland.

Sawyer, T. (1989). Noble Art: An Artistic \& Literary Celebration of the Old English Prize-Ring. London: Unwin Hyman.

Shaw, B.G. (1927). The Admirable Bashville: Or, Constancy Unrewarded: Being the Novel of Cashel Byron's Profession, Done into a Stage Play in 3 Acts and in Blank Verse. London: Constable.

Scott, D. (2008). The Art and Aesthetics of Boxing. Lincoln: University of Nebraska Press.

Streible, D. (2008). Fight Pictures: A History of Boxing and Early Cinema. Berkeley: California University Press.

Streible, D. (2005). On the Canvas: Boxing, Art, and Cinema. In N.M. Mathews \& C. Musse (Eds.), Moving Pictures: American Art and Early Film 1880-1910 (pp. 111-16). Manchester [VT]: Hudson Hills Press.

Tyson, B. (1996). Introduction. In B. Tyson (Ed.), Bernard Shaw's Book Reviews, II: 1884 to 1950. Brian: Pennsylvania State University.

Tunney, J.R. (2010). The Prizefighter and the Playwright: Gene Tunney and Bernard Shaw. Ontario: Firefly.

Tunney, J.R. (2003). The Playwright and the Prizefighter: Bernard Shaw and Gene Tunney. SHAW the Annual of Bernard Shaw Studies, 23, 149-154.

Weintraub, S. (1999). Cetewayo: Shaw's first hero from history. In G.K. Larson (Ed.), Shaw and History, Shaw volume 19 (pp. 7-22). Pennsylvania: Pennsylvania State University.

Weiss, S.A. (1986). Bernard Shaw's Letters to Siegfried Trebitsch. Stanford: Stanford University Press.

\section{AUTHOR'S ADDRESS: Jorge Knijnik}

University of Western Sydney - School of Education - Bankstown Campus

Locked Bag - 1797 - Penrith - 2751

NSW - AUSTRALIA

Email: j.knijnik@uws.edu.au 